\title{
Fungsi Izin Dalam Pengendalian Pencemaran Lingkungan (Studi Kasus: Gugatan Penerbitan Izin Pembuangan Limbah Cair Di Sungai Cikijing)
}

\author{
Nadia Astriani ${ }^{1}$ \\ Yulinda Adharani ${ }^{2}$
}

\begin{abstract}
Abstraksi
Permasalahan pencemaran dan/atau kerusakan lingkungan di Kecamatan Rancaekek, Kabupaten Bandung, sudah berlangsung lebih dari 20 tahun. Pencemaran Sungai Cikijing berdampak pada menurunnya produksi pertanian dan/atau perikanan. Pencemaran ini seharusnya tidak terjadi jika perusahaan mengolah limbah sebagaimana mestinya. Oleh karena itu Koalisi Melawan Limbah yang terdiri dari Wahana Lingkungan Hidup Jawa Barat (WALHI Jabar), Lembaga Bantuan Hukum (LBH) Bandung, dan Paguyuban Warga Peduli Lingkungan (PAWAPELING) menggugat penerbitan Izin Pembuangan Limbah Cair (IPLC) ke Sungai Cikijing yang dikeluarkan oleh Bupati Sumedang. Penelitian ini menggunakan metode penelitian yuridis-normatif, penelitian ini akan memaparkan fungsi izin dalam pengendalian lingkungan dengan menganalisa teori-teori hukum perizinan dan teori-teori hukum lingkungan serta penerapan teori-teori ini dalam praktek. Kasus ini menunjukkan bahwa fungsi izin sebagai

1 Dosen Fakultas Hukum Universitas Padjadjaran, merupakan sekretaris Departemen Hukum Lingkungan, Tata Ruang, dan Agraria, bidang kekhususan hukum lingkungan. Menyelesaikan S1 Ilmu Hukum, dan S2 Ilmu Lingkungan di Universitas Padjadjaran

2 Dosen Fakultas Hukum Universitas Padjadjaran, merupakan anggota Departemen Hukum Lingkungan, Tata Ruang, dan Agraria, bidang kekhususan hukum lingkungan. Menyelesaikan S1 dan S2 Ilmu Hukum di Universitas Padjadjaran
\end{abstract}


pengendali kegiatan di Indonesia pada kenyataannya masih jauh dari yang diharapkan. Dalam kasus ini Sungai Cikijing yang telah tercemar menjadi korban dari pemberian izin pembuangan limbah cair oleh Bupati Sumedang kepada PT. Kahatex, PT. Five Star Textil dan PT. Insan Sandang Internusa. Seharusnya dalam menerbitkan izin, pemerintah juga harus memperhatikan asas-asas yang ada dalam Undang-Undang Nomor 32 Tahun 2009 tentang Perlindungan dan Pengelolaan Lingkungan Hidup. Selain itu, pemerintah harus melakukan pengawasan kepada perusahaan-perusahaan yang telah diberikan izinnya, karena itu merupakan kewajiban pemerintah dalam rangka melindungi dan mengelola lingkungan hidup.

Kata Kunci : izin, pencemaran lingkungan, Sungai Cikijing, izin pembuangan limbah cair

\section{Abstract}

The problems of pollution and / or damage to the environment in the district Rancaekek, Bandung regency, has lasted more than 20 years. As a result of the pollution is the contamination of the river Cikijing thus impacting the decline in agricultural production and / or fisheries. This contamination should not occur if the companies treat waste properly. Therefore, Koalisi Melawan Limbah consisting of the Wahana Lingkungan Hidup of West Java (WALHI Jabar), Lembaga Bantuan Hukum (LBH) Bandung, and Paguyuban Warga Peduli Lingkungan (PAWAPELING) sued the publishing permit Waste Disposal Liquid to River Cikijing issued by Sumedang Regent. This research will be presented in the Environmental Control consent function by analyzing theories licensing laws and theories of environmental law as well as the application of these theories in practice. This case shows that the consent function as a control activity in Indonesia in reality is still far from the expected. In this case Cikijing River is polluted because of granting discharge of effluent by Regent Sumedang against PT. Kahatex, PT.Five Star Textil and PT. Insan Clothing Internusa. Supposedly in issuing permit, the government must also consider the principles contained in Law No. 32 of 2009 on the Protection and Environmental Management. Other than that, the government should conduct surveillance to companies that have been granted permission, because it is the government's obligation to protect and manage the environment. 
Keywords : Permit, environmental pollution, Cikijing River, wastewater discharge permit.

\section{Pendahuluan}

Prinsip otonomi daerah yang telah ditegaskan dalam Undang-Undang Nomor 23 Tahun 2014 Tentang Pemerintahan Daerah selanjutnya disebut UU 23/2014, memberikan kewenangan kepada pemerintah daerah untuk mengambil kebijakan-kebijakan yang dianggap perlu dalam memberikan pelayanan kepada masyarakat. Salah satu bentuk kewenangan yang menjadi perhatian adalah kewenangan pemerintah daerah dalam menerbitkan izin, yang lahir berdasarkan wewenang yang diberikan oleh undang-undang kepada pemerintah daerah. ${ }^{3}$ Selain dalam UU 23/2014, kewenangan pemerintah daerah dalam menerbitkan izin juga diatur dalam Undang-Undang Nomor 32 Tahun 2009 tentang Perlindungan dan Pengelolaan Lingkungan Hidup selanjutnya disebut UU 32/2009. ${ }^{4}$

Dalam rangka pengendalian pencemaran lingkungan, pemerintah/ kelembagaan yang berwenang melakukan upaya akan pencegahan dan penanggulangan dampak negatif serta pemulihan kualitas lingkungan memiliki peran yang sangat penting. ${ }^{5}$ Salah satu bentuk pengendalian pencemaran lingkungan adalah izin lingkungan yang dikeluarkan oleh pemerintah. Izin lingkungan dikeluarkan oleh badan atau pejabat yang berwenang dalam bentuk Keputusan Tata Usaha Negara selajutnya disebut KTUN. ${ }^{6}$ KTUN adalah suatu penetapan tertulis yang dikeluarkan oleh badan atau pejabat tata usaha negara yang berisi tindakan hukum tata usaha negara yang berdasarkan peraturan

3 Lihat pasal 9 Undang-Undang Nomor 23 Tahun 2014 tentang Pemerintahan Daerah dan Lihat huruf K (tentang Pembagian Urusan Pemerintahan Bidang Lingkungan Hidup) Lampiran Undang-Undang Nomor 23 Tahun 2014 tentang Pemerintahan Daerah, Lembaran Negara Republik Indonesia Tahun 2014 Nomor 244.

4 Lihat Pasal 63 ayat (2) Undang-Undang Nomor 32 Tahun 2009 tentang Perlindungan dan Pengelolaan Lingkungan Hidup, Lembaran Negara Republik Indonesia Tahun 2009 Nomor 140.

5 Siti Sundari Rangkuti, Hukum Lingkungan dan Kebijakan Lingkungan Nasional, (Surabaya: Airlangga University Press, 1996), hlm. 4

6 Lihat Undang-Undang Nomor 51 Tahun 2009 mengenai Perubahan Kedua atas UndangUndang No. 5 Tahun 1986 tentang Peradilan Tata Usaha Negara, Lembaran Negara Republik Indonesia Tahun 2009 Nomor 160, Tambahan Lembaran Negara Republik Indonesia Nomor 5079 . 
perundang-undangan yang berlaku, yang bersifat konkret, individual, dan final, yang menimbulkan akibat hukum bagi seseorang atau juga badan hukum perdata. ${ }^{7}$

Dalam prakteknya, penerbitan suatu KTUN dapatjuga menimbulkan kerugian terhadap masyarakat karena adanya suatu unsur kesalahan atau kekeliruan. Diterbitkannya KTUN oleh badan atau pejabat berwenang yang mengandung unsur kesalahan yang mengakibatkan pencemaran lingkungan akan menimbulan kerugian bagi lingkungan dan masyarakat secara umum. Apabila hal ini terjadi, pihak yang dirugikan dapat mengajukan gugatan di peradilan tata usaha negara, dan meminta agar KTUN tersebut dibatalkan atau dinyatakan tidak sah. Gugatan seseorang atau badan hukum perdata yang merasa kepentingannya dirugikan ke peradilan tata usaha negara berisi tuntutan agar izin itu dinyatakan batal atau tidak sah oleh hakim. ${ }^{8}$

Izin Lingkungan mencantumkan jumlah dan jenis izin perlindungan dan pengelolaan lingkungan hidup. Dalam hal pengendalian pencemaran lingkungan, salah satu jenis izin yang harus dimiliki oleh pemrakarsa adalah izin pembuangan limbah cair selanjutnya disebut IPLC. ${ }^{9}$ IPLC adalah izin yang membolehkan pembuangan limbah oleh perusahaan ke sumber air yang disediakan oleh pemerintah daerah atau sumber air yang berada di bawah pengawasan pemerintah daerah. Untuk memperolah IPLC, perusahaan diharuskan untuk mengolah limbah cair yang dihasilkan sampai kepada suatu kadar yang tidak berbahaya sebelum dibuang ke dalam air. ${ }^{10}$ Namun dalam prakteknya, beberapa perusahaan belum melakukan pengolahan sebagaimana mestinya sehingga limbah cair yang dibuang ke badan air menimbulkan dampak negatif bagi lingkungan hidup dan menimbulkan pencemaran air pada sungai, sebagaimana yang terjadi pada Kasus Pencemaran di Sungai Cikijing.

Dalam berkas perkara Nomor 178/G/2015/PTUN Bandung yang diajukan oleh Koalisi Melawan Limbah ke PTUN Bandung, Koalisi Melawan Limbah

$7 \quad$ Pasal 1 angka 3 Undang-Undang No. 51 Tahun 2009 tentang Peradilan Tata Usaha Negara

8 Bandingkan dengan pendapat Siti Sundari Rangkuti, Op. Cit., hlm. 121.

9 Lihat Penjelasan Pasal 48 ayat (2) Peraturan Pemerintah Nomor 27 Tahun 2012 tentang Izin Lingkungan.

10 Bandingkan Pasal 20 ayat (3) Undang-Undang Nomor 32 Tahun 2009 tentang Perlindungan dan Pengelolaan Lingkungan Hidup 
menggugat Surat Keputusan Bupati Sumedang Nomor 660.31/Kep.509-IPLC/2014 tentang Izin Pembuangan Limbah Cair ke Sungai Cikijing bagi PT Kahatex tertanggal 7 Juli 2014; Surat Keputusan Bupati Sumedang Nomor 660.31/Kep.784IPLC/2014 tentang IPLC bagi PT Five Star Texile Indonesia tertanggal 30 Januari 2014; dan Surat Keputusan Bupati Sumedang Nomor 660.31/Kep.198-IPLC/2013 tentang IPLC ke Sungai Cikijing kepada PT. Insan Sandang Internusa. Koalisi yang terdiri dari Wahana Lingkungan Hidup Jawa Barat (Walhi Jabar), Lembaga Bantuan Hukum (LBH) Bandung, dan Paguyuban Warga Peduli Lingkungan (Pawapeling) menggugat izin yang diberikan oleh Bupati Sumedang kepada tiga perusahaan tekstil di Sumedang. Penggugat mendalilkan pembuangan limbah cair yang dilakukan oleh tiga perusahaan tersebut memperparah pencemaran di Sungai Cikijing.

Pencemaran berawal dari pembangunan industri di Kecamatan Cikeruh, Kabupaten Sumedang. Perusahaan-perusahaan yang beroperasi di daerah ini membentuk cluster industri yang sebagian besar menghasilkan limbah cair dan membuangnya ke badan air Sungai Cikijing. Dari puluhan perusahaan di sekitar Jalan Raya Rancaekek, yang berada di Kecamatan Cikeruh, terdapat 3 Perusahaan yaitu: PT. Kahatex, PT. Insan Sandang dan PT Five Star, yang proses produksinya maupun debit limbah cairnya diduga memberikan konstribusi signifikan terhadap peningkatan beban pencemaran Sungai Cikijing. Pencemaran Sungai Cikijing dibuktikan dengan sudah terlampauinya Baku Mutu Air Permukaan sungai tersebut. Karena tidak ada sumber air lainnya, air yang sudah tercemar berbagai bahan kimia (termasuk logam berat) ${ }^{11}$ tetap dipergunakan untuk mengairi sawah dan kolam ikan, bahkan dipakai juga untuk mandi, cuci dan memasak. Luas areal pertanian dan perikanan yang terkena dampak pencemaran di 4 (empat) desa \pm 415 hektar. Jumlah penduduk di keempat desa tersebut lebih dari 50.000 orang.

11 Dalam kompilasi hasil riset AMDAL, parameter kimia yang telah melampaui baku mutu berdasarkan PP No.82 Tahun 2001 tentang Pengelolaan Kualitas Air dan Pengendalian Pencemaran Air kelas II yaitu : Amonium bebas dan Nitrit (NO2-N), sedangkan parameter lainnya yang konsentrasinya cukup tinggi adalah Seng (Zn), Kamium (Cd), Krom hexavalen, tembaga $(\mathrm{Cu})$, Timabl $(\mathrm{Pb})$, fenol.Tingginya parameter tersebut memungkinkan bersumber dari aktifitas industri pada bagian hulunya. Konsentrasi BOD berkisar antara 48,522 - 110,725 mg/l sedangkan baku mutu menetapkan $6 \mathrm{mg} / \mathrm{l}$, cukup tingginya BOD dimungkinkan pengaruh buangan limbah cair dari aktivitas domestik/pemukiman serta niaga. Adapun COD nilainya berkisar antara 82,191 - 1205,377 mg/l dan baku mutu menetapkan konsentrasi maksimum adalah $50 \mathrm{mg} / 1$, sehingga tidak memenuhi baku mutu. 
Terjadinya pencemaran lingkungan diindikasikan dengan menurunnya kualitas lahan pertanian dan menyebabkan menurunnya produksi, bahkan menyebabkan kematian tanaman padi atau bulir padinya hampa dan ikan yang mati. Selain itu, terdapat indikasi kuat bahwa pencemaran di kawasan tersebut telah menyebabkan meningkatnya berbagai penyakit, termasuk penyakit dalam. Persoalan pencemaran lingkungan, yang semula hanya berdimensi teknis, telah berkembang ke dimensi sosial, hukum, ekonomi, kesehatan, keamanan, bahkan politik dan budaya. ${ }^{12}$

Berdasarkan latar belakang masalah, maka permasalahan yang akan dibahas dalam artikel ini, apakah fungsi izin sebagai pengendali kegiatan dapat berperan secara optimal dalam pelestarian fungsi lingkungan? Dan bagaimana peran pengambil kebijakan dalam menilai permohonan izin yang diajukan, baik dari sisi mandat maupun implementasinya? Tujuan dari penelitian ini adalah untuk mengetahui peran pengambil kebijakan, khususnya pemberi izin, dalam menilai permohonan izin yang diajukan, sehingga fungsi izin sebagai pengendali kegiatan dapat diterapkan secara optimal dengan melihat kasus gugatan penerbitan izin pembuangan limbah cair PT. Kahatex, PT. Five Star Textil Dan PT. Insan Sandang Internusa.

Kajian hukum atas Fungsi Izin Dalam Pengendalian Pencemaran Lingkungan (Studi Kasus: Gugatan Penerbitan Izin Pembuangan Limbah Cair di Sungai Cikijing) ini dilakukan dengan menggunakan metode pendekatan yuridis normatif dalam arti menggunakan data kepustakaan/ sekunder (baik berupa bahan hukum primer, bahan hukum sekunder maupun bahan hukum tersier) sebagai bahan utama penelitian. Dalam hal ini digunakan metode penelitian yang bersifat deskriptif analitis dengan pendekatan sistemik.

Analisis yuridis kualitatif digunakan dengan mengandalkan pada kemampuan abstraksi-teoritis atas bahan-bahan hukum di atas, dengan menggunakan metode penafsiran hukum dan konstruksi hukum atas peraturan perundang-undangan terkait materi kajian. Pengumpulan data dilakukan dengan studi kepustakaan. Data kepustakaan diperoleh dari perpustakaan perguruan tinggi yang diperkirakan memiliki kompetensi di bidang yang terkait dengan materi penelitian termasuk

12 Lihat Bagian D. dalam Pokok Sengketa Gugatan dalam berkas perkara Nomor 178/G/2015/PTUN Bandung 
pada instansi atau lembaga-lembaga penelitian dan lembaga negara yang terkait dengan materi penelitian. Selain studi pustaka, pengumpulan informasi dilakukan dengan menggunakan metode wawancara dengan nara sumber yang ditentukan secara purposif (judgemental). Wawancara dilakukan secara terarah dengan menggunakan pedoman wawancara yang telah disusun sebagai arahannya.

\section{Kerangka Hukum Pengelolaan Kualitas dan Pengendalian Pencemaran Air}

\subsection{Perizinan Sebagai Instrumen Pengendali Pencemaran Lingkungan}

Izin merupakan suatu persetujuan dari penguasa berdasarkan undangundang atau peraturan pemerintah untuk dalam keadaan tertentu menyimpang dari ketentuan larangan perundang-undangan. ${ }^{13}$ Menurut Sjachran Basah, izin adalah "perbuatan hukum administrasi egara bersegi satu yang mengaplikasikan peraturan dalam hal concreto berdasarkan persyaratan dan prosedur sebagaimana ditetapkan oleh ketentuan peraturan perundang-undangan."14 Izin dapat dikatakan sebagai landasan hukum, dapat dipahami bahwa kegiatan tertentu memang tidak dapat dilakukan oleh warga masyarakat tanpa adanya izin dari organ pemerintah yang berwenang. Kenyataan tersebut dapat dimengerti karena berbagai hal sering kali terkait dengan kegiatan yang akan dilakukan oleh pemohon izin. Oleh karena itu, izin menjadi dasar hukum bagi pelaku kegiatan untuk dapat memulai kegiatan tersebut. Hak dan kewajiban pemohon izin berkaitan dengan dilakukannya kegiatan, lahir setelah adanya izin. Tanpa izin, suatu pihak tidak dapat melakukan kegiatan yang dimuat dalam izin itu. ${ }^{15}$

Menteri, Gubernur, Bupati/Walikota wajib melakukan pengawasan terhadap ketaatan penanggung jawab usaha. Kewenangan ini dapat didelegasikan kepada pejabat/instansi teknis yang bertanggung jawab. Selain itu, pemerintah dapat menetapkan pejabat pengawas lingkungan yang merupakan pejabat fungsional. Izin Lingkungan yang telah diperoleh oleh penanggung jawab usaha/kegiatan harus dilakukan sesuai dengan ketentuan yang seharusnya. Menteri, Gubernur,

13 Philipus M. Hadjon, Pengantar Hukum Perizinan, (Yuridika, Surabaya, 1993), hlm. 2-3.

14 Sjachran Basah, Pencabutan Izin Salah Satu Sanksi Hukum Administrasi. Makalah pada Penataran Hukum Administrasi dan Lingkungan di Fakultas Hukum Unair Surabaya, hlm. 3.

15 Y. Sri. Pudyatmoko, Perizinan Problem dan Upaya Pembenahan, (Grasindo, Jakarta, 2009), hlm. 22. 
Bupati/Walikota menerapkan sanksi administratif kepada penanggung jawab usaha/kegiatan jika dalam pengawasan ditemukan pelanggaran terhadap izin lingkungan.

Sistem perizinan lingkungan sebagai instrumen pencegahan kerusakan dan/ atau pencemaran lingkungan hidup hakikatnya merupakan pengendalian aktivitas pengelolaan lingkungan hidup. Oleh karena itu, pengaturan dan penyelenggaraan perizinan lingkungan harus didasarkan pada prinsip-prinsip yang terdapat dalam UU 32/2009. Secara teoritis, perizinan memiliki beberapa fungsi, yaitu ${ }^{16}$ :

1. Izin sebagai instrumen rekayasa pembangunan

Pemerintah dapat membuat regulasi dan keputusan yang memberikan insentif bagi pertumbuhan sosial ekonomi. Demikian juga sebaliknya, regulasi dan keputusan tersebut dapat pula menjadi penghambat (sekaligus sumber korupsi) bagi pembangunan.

2. Izin sebagai fungsi keuangan (budgetering)

Yaitu izin menjadi sumber pendapatan bagi negara. Pemberian izin dilakukan dengan kontraprestasi berupa retribusi perizinan. Negara mendapatkan kedaulatan dari rakyat, maka retribusi perizinan hanya bisa dilakukan melalui peraturan perundang-undangan. Dalam hal ini dianut prinsip no taxation without the law.

3. Izin sebagai fungsi pengaturan (reguleren)

Yaitu menjadi instrumen pengaturan tindakan dan perilaku masyarakat. Sebagaimana prinsip pemungutan pajak, perizinan dapat mengatur pilihanpilihan tindakan dan perilaku masyarakat. Jika perizinan terkait dengan pengaturan untuk pengelolaan sumber daya alam, lingkungan, tata ruang, dan aspek strategis lain, prosedur dan syarat yang harus ditetapkan oleh peraturan perundang-undangan harus pula dengan pertimbangan-pertimbangan strategis. Harus ada keterkaitan antara tujuan pemberian perizinan dengan syarat-syarat yang ditetapkan dalam izin.

4. Izin sebagai fungsi pengendalian

Pemerintah melakukan pengendalian terhadap kegiatan masyarakat dengan

16 Adrian Sutedi, dalam Helmi, Hukum Perizinan Lingkungan Hidup, (Jakarta Sinar Grafika 2012), hlm. 81-87. 
menggunakan instrumen perizinan. Izin dimaksudkan untuk mencapai berbagai tujuan tertentu.

Izin sebagai suatu bentuk keputusan yang dibuat oleh pejabat yang berwenang, atau sebagai ketetapan tertulis yang dikeluarkan oleh badan atau pejabat tata usaha negara bersifat konkret, individual dan final, yang menimbulkan akibat hukum bagi seseorang atau badan hukum perdata. ${ }^{17}$

Efektifitas dan efisiensi pengendalian pencemaran air dipengaruhi oleh salah satu instrumen pencegahan pencemaran lingkungan yaitu perizinan. Dalam Pasal 14 UU 32/2009 tentang Perlindungan dan Pengelolaan Lingkungan Hidup, disebutkan bahwa izin merupakan salah satu instrumen pencegahan pencemaran dan/atau kerusakan lingkungan. Perusahaan yang kegiatannya berdampak pada lingkungan harus memiliki izin lingkungan. Izin Lingkungan terdiri dari izin perlindungan dan pengelolaan lingkungan, salah satu jenis dari izin perlindungan dan pengelolaan lingkungan adalah izin pembuangan limbah cair (IPLC). ${ }^{18}$ Izin pembuangan limbah cair adalah pembuangan limbah ke sumber air yang disediakan Pemerintah Daerah atau sumber air yang berada di bawah pengawasan Pemerintah Daerah. Izin ini sesungguhnya mutlak adanya bagi setiap usaha atau perusahaan yang aktivitasnya menimbulkan limbah cair. Dengan tiadanya izin ini, maka membuang limbah langsung ke sungai adalah perbuatan melanggar hukum dan dapat dikenai sanksi. ${ }^{19}$

Penggunaan izin sebagai instrumen pengawasan ditunjukkan dengan pemberian izin-izin tertentu bagi aktivitas masyarakat. Berbagai persyaratanpersyaratan dalam pengurusan izin merupakan pengendali dalam memfungsikan izin itu sebagai alat untuk mengawasi aktivitas masyarakat, dan perbuatan yang dimintakan izin adalah perbuatan yang memerlukan pengawasan khusus. Pengawasan dibutuhkan sebagai perlindungan hukum bagi warga negara terhadap dampak dari penerbitan keputusan tata usaha negara. Pemerintah

17 Lihat Pasal 1 ayat 3 Undang-Undang Nomor 5 Tahun 1986 tentang Peradilan Tata Usaha Negara

18 Bandingkan Penjelasan Pasal 48 ayat (2) Peraturan Pemerintah Nomor 27 Tahun 2012 tentang Izin Lingkungan

19 Muhammad Subhi, Perizinan Pembuangan Limbah Cair Kegiatan Industri Dalam Hubungannya Dengan Pengendalian Pencemaran Air (Studi Di Kabupaten Ketapang), Jurnal Universitas Tanjungpura, Vol. 2 No. 2 Tahun 2012, hlm. 10. 
menjalankan pemerintahan melalui pengambilan keputusan pemerintahan yang bersifat strategis, policy atau ketentuan-ketentauan umum melalui tindakantindakan pemerintahan yang bersifat menegakkan ketertiban umum, hukum, wibawa negara, dan kekuasaan negara.

Dalam UU 32/2009 terdapat asas-asas yang berkaitan dengan kasus yang akan dibahas, antara lain ialah asas tanggungjawab negara; asas kelestarian dan keberlanjutan; asas kehati-hatian; asas partisipatif; serta asas tata kelola pemerintah yang baik. Asas-asas ini seharusnya diperhatikan oleh pemberi izin sebelum mengeluarkan izin (dalam hal ini Bupati Sumedang). Selain asas ini, terdapat pula pengaturan mengenai apa yang harus dilakukan oleh pemberi izin apabila hasil analisis daya tampung beban pencemaran air melewati batas.

"Bupati/walikota wajib menolak permohonan izin yang diajukan penanggungjawab usaha dan/atau kegiatan apabila berdasarkan hasil analisis penetapan daya tampung beban pencemaran air menunjukkan bahwa rencana lokasi usaha dan/atau kegiatan yang diajukan merupakan faktor penyebab terlewatinya daya tampung beban pencemaran air." 20

\subsection{Pengendalian Pencemaran Lingkungan Melalui Baku Mutu Lingkungan}

Masalah lingkungan di negara yang sedang berkembang seperti Indonesia, berbeda dengan masalah lingkungan di negara maju atau negara industri. Masalah lingkungan di negara maju disebabkan oleh pencemaran sebagai akibat sampingan yang menggunakan banyak energi, teknologi maju yang boros energi pada industri, kegiatan transportasi dan komunikasi serta kegiatan-kegiatan ekonomi lainnya. Masalah lingkungan di Indonesia terutama berakar pada keterbelakangan pembangunan. Karena itu, apabila negara industri mempunyai pandangan yang kuat untuk mengatasi masalah lingkungan dengan tidak meningkatkan pembangunan, lazim dikenal dengan pertumbuhan nol (zero growth), bagi Indonesia justru untuk mengatasi masalah lingkungan diperlukan pertumbuhan ekonomi dengan meningkatkan pembangunan nasional. ${ }^{21}$

20 Pasal 12 Peraturan Menteri Lingkungan Hidup Nomor 1 Tahun 2010 tentang Tata Laksana Pengendalian Pencemaran Air

21 M Daud Silalahi, Hukum Lingkungan dalam Sistem Penegakan Hukum Lingkungan Indonesia, (Alumni, Bandung, 2001), hlm. 18 
Ketersediaan sumber daya alam secara kuantitas ataupun kualitas tidak merata, sedangkan kegiatan pembangunan membutuhkan sumber daya alam yang semakin meningkat. Kegiatan pembangunan juga mengandung risiko terjadinya pencemaran dan kerusakan lingkungan. Kondisi ini dapat mengakibatkan daya dukung, daya tampung, dan produktivitas lingkungan hidup menurun yang pada akhirnya menjadi beban sosial.

Dalam hukum lingkungan terdapat instrumen penaatan, instrumen penaatan ini penting karena dapat mencegah pencemaran dan dapat membuat perusahaan taat terhadap hukum lingkungan. Tujuan penaatan hukum lingkungan adalah mencegah terjadinya pencemaran dan/atau kerusakan dengan menerapkan persyaratan lingkungan terhadap kegiatan usaha dan/atau perorangan. ${ }^{22}$ Dalam UU 32/2009 dijelaskan mengenai instrumen penaatan hukum lingkungan, salah satunya adalah baku mutu lingkungan. ${ }^{23}$

Berkaitan dengan kasus yang akan dibahas, instrumen penaatan yang digunakan ialah baku mutu lingkungan karena dalam mengeluarkan IPLC, pemberi izin harus melihat kelas air ${ }^{24}$, daya tampung beban pencemaran $\operatorname{air}^{25}$, baku mutu ambien, serta baku mutu effluent dari sungai yang akan menampung beban limbah tersebut agar kualitas airnya tetap terjaga. Penentuan terjadinya pencemaran lingkungan hidup diukur melalui baku mutu lingkungan hidup. Baku mutu lingkungan hidup adalah "ukuran batas atau kadar makhluk hidup, zat, energi, atau komponen yang ada atau harus ada dan/atau unsur pencemar yang ditenggang keberadaannya dalam suatu sumber daya tertentu sebagai unsur lingkungan hidup." 26 Sedangkan baku mutu air adalah "ukuran batas atau kadar

22 Nadia Astriani, Instrumen Ekonomi dalam Perspektif Penaatan Hukum Lingkungan, dalam Prosiding Perkembangan Hukum Lingkungan Kini dan Masa Depan, (LoGoz Publishing: Bandung 2013), hlm. 511.

23 Lihat Pasal 14 Undang-Undang Nomor 32 Tahun 2009 tentang Perlindungan dan Pengelolaan Lingkungan Hidup

24 Kelas air adalah peringkat kualitas air yang dinilai masih layak untuk dimanfaatkan bagi peruntukan tertentu(Pasal 1 angka 6 Peraturan Pemerintah Nomor 82 Tahun 2001Pengelolaan Kualitas Air dan Pengendalian Pencemaran Air)

25 Daya tampung beban pencemaran adalah kemampuan air pada suatu sumber air, untuk menerima masukan beban pencemaran tanpa mengakibatkan air tersebut menjadi cemar (Pasal 1 angka13 Peraturan Pemerintah Nomor 82 Tahun 2001Pengelolaan Kualitas Air dan Pengendalian Pencemaran Air)

26 Lihat Pasal 1 Angka 13 Undang-Undang Nomor 32 Tahun 2009 tentang Perlindungan dan Pengelolaan Lingkungan Hidup 
makhluk hidup, zat, energi, atau komponen yang ada atau harus ada dan atau unsur pencemar yang ditenggang keberadaannya di dalam air." 27

Baku mutu lingkungan merupakan instrumen teknis untuk menentukan terjadinya pencemaran lingkungan hidup akibat pelaksanaan suatu izin usaha dan/ atau kegiatan. Agar lingkungan hidup mampu mendukung kegiatan pembangunan yang berkesinambungan, usaha untuk memelihara dan mengembangkan mutu lingkungan hidup Indonesia penting. ${ }^{28}$

Baku mutu air bukan hanya merupakan salah satu instrumen penaatan lingkungan, tetapi baku mutu air juga dapat menjadi instrumen pengelolaan lingkungan. Hal ini dikarenakan dengan ditetapkannya baku mutu air pada sumber air dan memperhatikan kondisi airnya, akan dapat dihitung berapa beban zat pencemar yang dapat ditenggang adanya oleh air penerima sehingga air dapat tetap berfungsi sesuai dengan peruntukannya. Beban pencemaran ini merupakan daya tampung beban pencemaran bagi air penerima yang telah ditetapkan peruntukannya. ${ }^{29}$

Terdapat syarat administrasi dan syarat teknis dalam pengajuan permohonan IPLC, syarat administrasi yang dimaksud adalah formulir izin; izin yang berkaitan dengan usaha/kegiatan; serta dokumen AMDAL/UKL-UPL/dokumen lain yang dipersamakan. ${ }^{30}$ Sedangkan yang dimaksud syarat teknis ialah upaya pencegahan pencemaran, minimisasi air limbah, serta efisiensi energi dan sumberdaya yang harus dilakukan oleh penanggungjawab usaha dan/atau kegiatan yang berkaitan dengan pengelolaan air limbah; dan kajian dampak pembuangan air limbah terhadap pembudidayaan ikan, hewan, dan tanaman, kualitas tanah dan air tanah, serta kesehatan masyarakat. ${ }^{31}$

27 Penjelasan Pasal 20 Undang-Undang Nomor 32 Tahun 2009 tentang Perlindungan dan Pengelolaan Lingkungan Hidup

28 M Daud Silalahi, Hukum Lingkungan dalam Sistem Penegakan Hukum Lingkungan Indonesia, (Alumni Bandung 2001), hlm. 116

29 Lihat Penjelasan Peraturan Pemerintah Nomor 82 Tahun 2001 tentang Pengelolaan Kualitas Air dan Pengendalian Pencemaran Air.

30 Bandingkan Pasal 23 ayat (1) Peraturan Menteri Lingkungan Hidup Nomor 1 Tahun 2010 tentang Tata Laksana Pengendalian Pencemaran Air

31 Lihat Pasal 23 ayat (2) Peraturan Menteri Lingkungan Hidup Nomor 1 Tahun 2010 tentang Tata Laksana Pengendalian Pencemaran Air 


\section{Pembahasan}

Setiap orang berkewajiban memelihara kelestarian fungsi lingkungan hidup serta mencegah dan menanggulangi pencemaran dan perusakan lingkungan hidup. Untuk dapat melakukan kegiatan yang kemungkinan berpengaruh terhadap lingkungan hidup tersebut, maka seseorang atau suatu badan hukum harus memiliki izin. Izin tersebut akan diawasi oleh pemberi izin dalam upaya menjaga kelestarian fungsi lingkungan. ${ }^{32}$

Melalui instrumen izin, maka pemerintah (dalam kasus ini Pemerintah Kabupaten Sumedang) dapat membatasi aktivitas yang berpengaruh pada lingkugan hidup agar tidak terjadi kerusakan atau menimbulkan bahaya pada lingkungan atau masyarakat sekitar. Sebagai suatu instrumen, izin berfungsi sebagai pengarah, untuk mengarahkan tingkah laku warga. Perizinan juga memiliki fungsi pembinaan, pengaturan, pengendalian dan pengawasan. Izin dikeluarkan oleh penguasa sebagai instrumen untuk mempengaruhi hubungan dengan para warga agar mau mengikuti cara yang dianjurkannya guna mencapai tujuan yang konkret. ${ }^{33}$

Dalam UU 32/2009, asas yang dianut adalah asas otonomi daerah. Asas ini memberikan dasar bagi pemerintah dan pemerintah daerah untuk mengatur dan mengurus sendiri urusan pemerintahan di bidang perlindungan dan pengelolaan lingkungan hidup dengan memperhatikan kekhususan dan keragaman daerah. ${ }^{34}$

Kasus yang diangkat oleh penulis dalam tulisan ini adalah kasus pembuangan limbah cair ke Sungai Cikijing. Sungai Cikijing merupakan sungai yang melintasi 2 kabupaten yaitu, Kabupaten Sumedang dan Kabupaten Bandung, Sungai Cikijing pada awalnya merupakan sungai alami yang berfungsi sebagai irigasi sawah di dua

32 Bandingkan Pasal 67 Undang-Undang Nomor 32 Tahun 2009 tentang Perlindungan Pengelolaan Lingkungan Hidup

33 Santi H D Adikancana, Tinjauan Yuridis Kewenangan Pemerintah dalam Hal Penegakan Hukum Lingkungan dan Penerapan Sanksi Administratif, dalam Prosiding Perkembangan Hukum Lingkungan Kini dan Masa Depan, (LoGoz Publishing: Bandung 2013), hlm. 490.

34 Lihat Pasal 1 huruf n Penjelasan Undang-Undang Nomor 32 Tahun 2009 tentang Perlindungan dan Pengelolaan Lingkungan Hidup 
kabupaten tersebut serta perairan bagi perikanan, peternakan dan perkebunan. ${ }^{35}$ Sungai Cikijing yang berada di Kabupaten Bandung, melewati 4 desa, yaitu Desa Jelegong, Desa Linggar, Desa Sukamulya dan Desa Bojong Loa, di mana keempat Desa tersebut adalah Kawasan Pertanian Lahan Basah dan Kawasan Pemukiman. ${ }^{36}$ Sungai Cikijing juga sering dipakai oleh para petani dan peternak di keempat desa tersebut untuk mengairi sawahnya dan menghidupi hewan ternaknya, namun dari tahun 1994-2000 para petani dan peternak mengalami kerugian, hingga di tahun 2000 hingga sekarang banyak petani yang gulung tikar, dan tidak sedikit petani yang enggan menyewa lahan atau memakai lahannya untuk bertani kembali, begitu pula para peternak. Menurut data yang diperoleh dari Dinas Pertanian dan Kehutanan Kabupaten Bandung, Hingga tahun 2009 lahan sawah yang tercemar limbah industri di Desa Linggar, Sukamulya, Jelegong, dan Bojongloa seluas $415 \mathrm{Ha}$ atau $42,2 \%$ dari total baku lahan sawah (983 Ha) di keempat desa tersebut dengan hasil sekitar 0,50 - 0,60 ton $\mathrm{GK} / \mathrm{H}$, sehingga penurunan produktivitas lahan sawah dari 1993 hingga 2009 pada 4 desa tersebut merosot hingga 91,17 \%. ${ }^{37}$

35 Lihat Bagian D. dalam Pokok Sengketa Gugatan dalam berkas perkara Nomor 178/G/2015/PTUN Bandung

36 Lihat Peraturan Daerah Kabupaten Bandung No 3 Tahun 2008 tentang RTRW Kabupaten Bandung 2007 - 2027,

37 BPLHD Jabar, Pengantar Diskusi (FGD) Bedah Kasus Pencemaran dan/atau Kerusakan Lingkungan di Kecamatan Rancaekek, Kabupaten Bandung: "Meretas Jalan Panjang Menggapai Kebenaran dan Keadilan", http://www.bplhdjabar.go.id/index.php/layanan/k2-categories-2/item/41pengantar-diskusi-fgd-bedah-kasus-pencemaran-dan-atau-kerusakan-lingkungan, diakses pada tanggal 28 Maret 2016 Pk. 14.00 WIB 


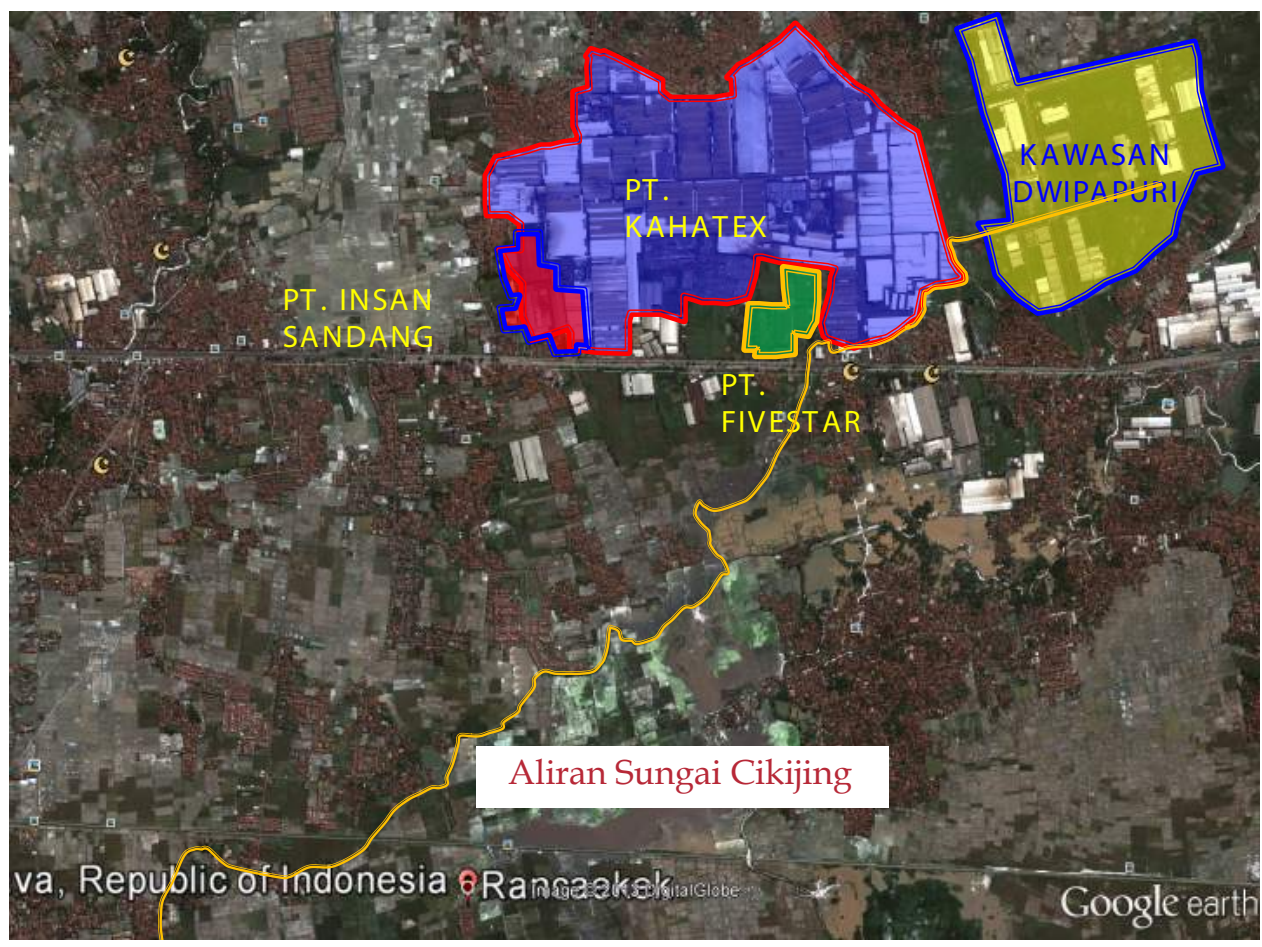

Gambar 1. Peta Sungai Cikijing (Sumber: Google Earth, 2016)

Masing-masing surat Keputusan Bupati Sumedang ${ }^{38}$ menimbulkan akibat hukum bagi PT. Kahatex, PT Five Star Textile Indonesia dan PT Insan Sandang Internusa sehingga dapat membuang limbah cair ke Sungai Cikijing di Desa Cisempur dan Desa Cintamulya, Kecamatan Jatinangor, Kabupaten Sumedang. Atas dasar Surat Keputusan itulah Koalisi Melawan Limbah yang terdiri dari Wahana Lingkungan Hidup Jawa Barat (WALHI Jabar), Lembaga Bantuan Hukum (LBH) Bandung, dan Paguyuban Warga Peduli Lingkungan (PAWAPELING) menggugat penerbitan Izin Pembuangan Limbah Cair (IPLC) ke Sungai Cikijing ke Pengadilan Tata Usaha Negara Bandung dengan berkas perkara bernomor 178/G/2015/PTUN Bandung. Koalisi Melawan Limbah beranggapan bahwa Sungai Cikijing telah tercemar dan seharusnya Bupati Sumedang tidak menerbitkan

38 Surat Keputusan Bupati Sumedang Nomor 660.31/Kep.509-IPLC/2014 tentang IPLC ke Sungai Cikijing bagi PT Kahatex tertanggal 7 Juli 2014, Surat Keputusan Bupati Sumedang Nomor 660.31/Kep.784-IPLC/2014 tentang IPLC bagi PT Five Star Texile Indonesia tertanggal 30 Januari 2014, dan Surat Keputusan Bupati Sumedang Nomor 660.31/Kep.198IPLC/2013 tentang IPLC ke Sungai Cikijing kepada PT. Insan Sandang Internusa. 
Izin Pembuangan Limbah Cair ke Sungai Cikijing. Hal ini dapat dilihat dari hasil uji baku mutu air permukaan sungai Cikijing di bawah ini.

Hasil Uji Baku Mutu Air Permukaan Sungai Cikijing Tahun 2013

\begin{tabular}{|c|c|c|c|c|c|c|c|}
\hline NO & PARAMETER & SAT & $\begin{array}{l}\text { Bulan } \\
\text { Februari }\end{array}$ & $\begin{array}{c}\text { Bulan } \\
\text { Agustus }\end{array}$ & $\begin{array}{c}\text { Bulan } \\
\text { Desember }\end{array}$ & $\begin{array}{l}\text { BAKU } \\
\text { MUTU }\end{array}$ & $\begin{array}{l}\text { METODE/ } \\
\text { STANDAR }\end{array}$ \\
\hline \multicolumn{8}{|c|}{ Parameter Fisika } \\
\hline 1 & Temperatur & ${ }^{0} \mathrm{C}$ & 30,2 & 27,4 & 34,2 & deviasi 3 & SNI 06 6989.23-2005 \\
\hline 2 & $\begin{array}{l}\text { TDS (Residu } \\
\text { Terlarut) }\end{array}$ & $\mathrm{mg} / \mathrm{L}$ & 1187 & 2093 & 2707 & 1000 & SNI 06-6989.27-2005 \\
\hline 3 & $\begin{array}{l}\text { TSS (Residu } \\
\text { Tersuspensi) }\end{array}$ & $\mathrm{mg} / \mathrm{L}$ & 229 & 280 & 56 & 50 & SNI 06-6989.3-2004 \\
\hline 4 & DHL & $\mu \mathrm{S} / \mathrm{cm}$ & 1,760 & 3,050 & 4,15 & - & Metoda TOA DKK \\
\hline \multicolumn{8}{|c|}{$\begin{array}{l}\text { Parameter } \\
\text { Kimia }\end{array}$} \\
\hline 1 & $\mathrm{Ph}$ & - & 7,50 & 7,63 & 7,72 & $6-9$ & SNI 06 6989.11-2004 \\
\hline 2 & $\mathrm{BOD}_{5}$ & $\mathrm{mg} / \mathrm{L}$ & 26 & 171 & 109 & 3 & SNI 06-2503-1991 \\
\hline 3 & COD & $\mathrm{mg} / \mathrm{L}$ & 78 & 268 & 270 & 25 & HACH Method 8000 \\
\hline 4 & DO*) & $\mathrm{mg} / \mathrm{L}$ & 3,5 & 5,7 & 1,9 & $>4$ & Metoda TOA DKK \\
\hline 5 & $\begin{array}{l}\text { Phosphat } \\
\left(\mathrm{PO}_{4}^{3-}-\mathrm{P}\right)\end{array}$ & $\mathrm{mg} / \mathrm{L}$ & 0,08 & 0,63 & 0,49 & 0,2 & APPA AWWA 4500 \\
\hline 6 & $\begin{array}{l}\text { Nitrat } \\
\left(\mathrm{NO}_{3}-\mathrm{N}\right)\end{array}$ & $\mathrm{mg} / \mathrm{L}$ & $<0,2$ & 8,4 & 35 & 10 & HACH Method 8171 \\
\hline 7 & $\operatorname{Kadmium}(\mathrm{Cd})$ & $\mathrm{mg} / \mathrm{L}$ & $<0,01$ & $<0,01$ & $<0,01$ & 0,01 & SNI 06-6989.16-2004 \\
\hline 8 & $\begin{array}{l}\text { Krom } \\
\text { Heksavalen } \\
(\mathrm{Cr}+6)\end{array}$ & $\mathrm{mg} / \mathrm{L}$ & $<0,016$ & $<0,016$ & 0,03 & 0,05 & APPA AWWA \\
\hline 9 & $\begin{array}{l}\text { Tembaga } \\
(\mathrm{Cu})\end{array}$ & $\mathrm{mg} / \mathrm{L}$ & $<0,07$ & $<0,07$ & $<0,07$ & 0,02 & SNI 06-6989.6-2004 \\
\hline 10 & Timbal $(\mathrm{Pb})$ & $\mathrm{mg} / \mathrm{L}$ & $<0,35$ & $<0,35$ & $<0,35$ & 0,03 & SNI 06-6989.8-2004 \\
\hline 11 & Seng (Zn) & $\mathrm{mg} / \mathrm{L}$ & 0,1155 & 0,1059 & 0,0864 & 0,05 & SNI 06-6989.7-2004 \\
\hline 12 & Sianida $\left(\mathrm{CN}^{-}\right)$ & $\mathrm{mg} / \mathrm{L}$ & 0,011 & 0,012 & $<0,008$ & 0,02 & HACH Method 8027 \\
\hline 13 & Fluorida (F-) & $\mathrm{mg} / \mathrm{L}$ & 0,3 & 0,58 & 0,76 & 1,5 & HACH Method 8029 \\
\hline 14 & Nitrit (NO2-N) & $\mathrm{mg} / \mathrm{L}$ & 0,02 & 0,2 & 0,150 & 0,06 & HACH Method 8507 \\
\hline 15 & $\begin{array}{l}\text { Klorin Bebas } \\
\left(\mathrm{Cl}_{2}\right)\end{array}$ & $\mathrm{mg} / \mathrm{L}$ & 0,11 & 0,17 & $<0,02$ & 0,03 & HACH Method 8021 \\
\hline \multicolumn{8}{|c|}{ Parameter Mikrobiologi } \\
\hline 1 & Total Coliform & $\mathrm{Jml} / 0,1 \mathrm{~L}$ & 395 & 380 & 53000 & 5000 & SNI 06-6858-2002 \\
\hline
\end{tabular}




\begin{tabular}{|c|c|c|c|c|c|c|c|}
\hline \multicolumn{8}{|c|}{ Kimia Organik } \\
\hline 1 & Detergen & $\mathrm{mg} / \mathrm{L}$ & 0,082 & 0,039 & 0,058 & 0,2 & HACH Method 8028 \\
\hline 2 & Fenol & $\mathrm{mg} / \mathrm{L}$ & 0,0270 & 0,0961 & 0,0530 & 0,001 & JIS K 0102 : 1998, 28 \\
\hline NO & PARAMETER & SAT & \multicolumn{4}{|c|}{ Bulan Mei } & Bulan September \\
\hline \multicolumn{8}{|c|}{ Parameter Fisika } \\
\hline 1 & Temperatur & ${ }^{\circ} \mathrm{C}$ & \multicolumn{4}{|c|}{31,2} & 29,8 \\
\hline 2 & $\begin{array}{l}\text { TDS (Residu } \\
\text { Terlarut) }\end{array}$ & $\mathrm{mg} / \mathrm{L}$ & \multicolumn{4}{|c|}{540} & 2910 \\
\hline 3 & $\begin{array}{l}\text { TSS (Residu } \\
\text { Tersuspensi) }\end{array}$ & $\mathrm{mg} / \mathrm{L}$ & \multicolumn{4}{|c|}{58} & 48 \\
\hline \multicolumn{8}{|c|}{$\begin{array}{l}\text { Parameter } \\
\text { Kimia }\end{array}$} \\
\hline 1 & $\mathrm{pH}$ & - & \multicolumn{4}{|c|}{7,17} & 8,23 \\
\hline 2 & $\mathrm{BOD}_{5}$ & $\mathrm{mg} / \mathrm{L}$ & \multicolumn{4}{|c|}{6} & 152 \\
\hline 3 & COD & $\mathrm{mg} / \mathrm{L}$ & \multicolumn{4}{|c|}{32} & 335 \\
\hline 4 & $\left.\mathrm{DO}^{*}\right)$ & $\mathrm{mg} / \mathrm{L}$ & \multicolumn{4}{|c|}{1,0} & 0,0 \\
\hline 5 & $\begin{array}{l}\text { Phosphat } \\
\left(\mathrm{PO}_{4}^{3--} \mathrm{P}\right)\end{array}$ & $\mathrm{mg} / \mathrm{L}$ & \multicolumn{4}{|c|}{0,14} & 1,36 \\
\hline 6 & Nitrat $\left(\mathrm{NO}_{3}-\mathrm{N}\right)$ & $\mathrm{mg} / \mathrm{L}$ & \multicolumn{4}{|c|}{2,1} & 3,5 \\
\hline 7 & Kadmium (Cd) & $\mathrm{mg} / \mathrm{L}$ & \multicolumn{4}{|c|}{$<0,01$} & $<0,004$ \\
\hline 8 & $\begin{array}{l}\text { Krom } \\
\text { Heksavalen } \\
(\mathrm{Cr}+6)\end{array}$ & $\mathrm{mg} / \mathrm{L}$ & \multicolumn{4}{|c|}{0,03} & 0,03 \\
\hline 9 & Tembaga $(\mathrm{Cu})$ & $\mathrm{mg} / \mathrm{L}$ & \multicolumn{4}{|c|}{$<0,07$} & 0,0710 \\
\hline 10 & Timbal $(\mathrm{Pb})$ & $\mathrm{mg} / \mathrm{L}$ & \multicolumn{4}{|c|}{$<0,35$} & $<0,09$ \\
\hline 11 & Seng $(\mathrm{Zn})$ & $\mathrm{mg} / \mathrm{L}$ & \multicolumn{4}{|c|}{0,0833} & $<0,06$ \\
\hline 12 & Sianida $\left(\mathrm{CN}^{-}\right)$ & $\mathrm{mg} / \mathrm{L}$ & \multicolumn{4}{|c|}{0,16} & 0,05 \\
\hline 13 & Fluorida (F-) & $\mathrm{mg} / \mathrm{L}$ & \multicolumn{4}{|c|}{0,37} & 0,28 \\
\hline 14 & Nitrit (NO2-N) & $\mathrm{mg} / \mathrm{L}$ & \multicolumn{4}{|c|}{0,173} & 3,4 \\
\hline 15 & $\begin{array}{l}\text { Klorin Bebas } \\
\left(\mathrm{Cl}_{2}\right)\end{array}$ & $\mathrm{mg} / \mathrm{L}$ & \multicolumn{4}{|c|}{0,10} & 0,33 \\
\hline \multicolumn{8}{|c|}{ Parameter Mikrobiologi } \\
\hline 1 & Fecal Coliform & $\mathrm{Jml} / 0,1 \mathrm{~L}$ & \multicolumn{4}{|c|}{50000} & 1240000 \\
\hline 2 & Total Coliform & $\mathrm{Jml} / 0,1 \mathrm{~L}$ & \multicolumn{4}{|c|}{290000} & 2600000 \\
\hline \multicolumn{8}{|c|}{ Kimia Organik } \\
\hline 1 & Detergen & $\mathrm{mg} / \mathrm{L}$ & \multicolumn{4}{|c|}{0,039} & 0,28 \\
\hline 2 & Fenol & $\mathrm{mg} / \mathrm{L}$ & \multicolumn{4}{|c|}{0,0527} & 0,1357 \\
\hline
\end{tabular}




\section{Hasil Uji Baku Mutu Air Permukaan Sungai Cikijing Tahun 2014}

Keterangan :

- Baku Mutu yang digunakan adalah Baku Mutu Air Kelas II PP 82 tahun 2001

- $\quad t t$ : Tidak Tertentu

- tanda Parameter melebihi Baku Mutu

Gambar 2. Hasil Uji Baku Mutu Air Permukaan Sungai Cikijing Tahun 2013 dan 2014 (Sumber: BPLHD Jawa Barat, 2016)

Berdasarkan hasil uji baku mutu air permukaan Sungai Cikijing tahun 2013 dan 2014 di atas, kriteria pencemar seperti (TSS) (TDS) (BOD) dan (COD) melebihi baku mutu, selain itu fisik dari airnya pun keruh, berwarna cokelat hingga hitam dan berbau. Menurut Hasil/Laporan Valuasi Ekonomi Dampak Pencemaran di Kawasan Industri Rancaekek dari Tim Peneliti UNPAD tahun 2015, dengan menggunakan pendekatan Total Economic Valuation (tanpa mengikutsertakan biaya abai baku mutu) maka nilai ekonomi total dari pencemaran di wilayah 4 Desa tersebut adalah sebesar Rp. 11.385.116.564.664,- (Sebelas triliun tiga ratus delapan puluh lima milyar seratus enam belas juta lima ratus enam puluh empat ribu enam ratus enam puluh empat rupiah). ${ }^{39}$

Walaupun Sungai Cikijing telah tercemar, tetapi Bupati Sumedang masih menerbitkan izin kepada PT Kahatex, PT Insan Sandang Internusa dan PT Five Star Textile Indonesia untuk membuang limbahnya ke Sungai Cikijing. Jangka waktu Izin Pembuangan Limbah Cair tersebut, Izin Pembuangan Limbah berjangka waktu 5 tahun dan pemegang izin harus melakukan daftar ulang per 1 tahun sekali. ${ }^{40}$ Selama beroperasi, ketiga perusahaan ini telah mendapatkan teguran, sanksi administrasi, pelaporan dari masyarakat, sanksi membayar ganti rugi terhadap masyarakat bahkan salah satu dari ketiga perusahaan tersebut pernah diberikan sanksi pidana karena tidak dioperasikannya IPAL, pembuangan limbah secara langsung dan pembuangan limbah yang melebihi baku mutu air limbah. ${ }^{41}$

\footnotetext{
39 BPLHD Jabar, Loc. Cit

40 LihatPasal 11 Keputusan Bupati Sumedang No. 26 Tahun 2013 tentang Izin Pembuangan Limbah Cair

41 Hasil Wawancara dengan Dhanur Santiko, Tim Kuasa Hukum Koalisi Melawan Limbah, LBH Bandung, 13 April 2016
} 
Berdasarkan yang telah diuraikan di atas, maka dalam penerbitan izin lingkungan Pejabat (dalam kasus ini Bupati Sumedang) harus mempertimbangkan berbagai asas yang termuat dalam pasal 2 UU 32/2009, yaitu di antaranya ${ }^{42}$ :

1. Asas tanggung jawab negara:

a. negara menjamin pemanfaatan sumber daya alam akan memberikan manfaat yang sebesar-besarnya bagi kesejahteraan dan mutu hidup rakyat, baik generasi masa kini maupun generasi masa depan;

b. negara menjamin hak warga negara atas lingkungan hidup yang baik dan sehat;

c. negara mencegah dilakukannya kegiatan pemanfaatan sumber daya alam yang menimbulkan pencemaran dan/atau kerusakan lingkungan hidup;

Apabila dikaitkan dengan kasus ini, asas tanggung jawab negara menjelaskan tentang kewajiban-kewajiban pemerintah daerah (dalam kasus ini Bupati Sumedang) termasuk di dalamnya pengawasan dan penegakkan hukum yang dilakukan demi pelestarian fungsi lingkungan. Dalam kasus ini, pemerintah telah lalai dalam melakukan pengawasan terhadap pembuangan limbah cair yang dilakukan oleh 3 perusahaan tersebut (dalam izin sebelumnya) sehingga IPLC dianggap layak untuk dikeluarkan. ${ }^{43}$

2. Asas kelestarian dan keberlanjutan, yaitu bahwa setiap orang memikul kewajiban dan tanggung jawab terhadap generasi mendatang dan terhadap sesamanya dalam satu generasi dengan melakukan upaya pelestarian daya dukung ekosistem dan memperbaiki kualitas lingkungan hidup;

Berkaitan dengan kasus, asas kelestarian dan keberlanjutan menjelaskan bahwa dalam menerbitkan kebijakan, pemerintah (dalam kasus ini Bupati Sumedang) harus memperhatikan kelestarian dan keberlanjutan dari lingkungan sekitarnya. Dengan dikeluarkannya IPLC oleh Bupati Sumedang, secara langsung yang bersangkutan tidak memperhatikan kelestarian dan keberlanjutan dari Sungai Cikijing dan lingkungan di sekitarnya.

42 Lihat Pasal 2 Penjelasan Undang-Undang Nomor 32 Tahun 2009 tentang Perlindungan dan Pengelolaan Lingkungan Hidup

43 Bandingkan Bagian D. dalam Pokok Sengketa Gugatan dalam berkas perkara Nomor 178/G/2015/ PTUN Bandung 
3. Asas kehati-hatian, yaitu bahwa ketidakpastian mengenai dampak suatu usaha dan/atau kegiatan karena keterbatasan penguasaan ilmu pengetahuan dan teknologi bukan merupakan alasan untuk menunda langkah-langkah meminimalisasi atau menghindari ancaman terhadap pencemaran dan/atau kerusakan lingkungan hidup;

Pemerintah harus mengedepankan asas ini untuk menghindari ancaman terhadap pencemaran dan/atau kerusakan lingkungan hidup. Dalam kasus yang dibahas, Bupati Sumedang tidak mengedepankan asas ini karena telah mengeluarkan IPLC. Hal ini juga diperkuat oleh Pertimbangan Hakim dalam Putusan Perkara Nomor 178/G/2015/PTUN Bandung yang menyatakan bahwa Bupati Sumedang tidak memperhatikan Asas Kehati-Hatian karena telah memberikan IPLC yang limbahnya dibuang ke sungai yang bukan hanya akan tercemar akan tetapi sudah tercemar.

4. Asas partisipatif, yaitu bahwa setiap anggota masyarakat didorong untuk berperan aktif dalam proses pengambilan keputusan dan pelaksanaan perlindungan dan pengelolaan lingkungan hidup, baik secara langsung maupun tidak langsung;

Asas partisipatif ini menjadi penting, khususnya dalam kasus Sungai Cikijing, adalah salah satu contoh nyata dimana pengambilan keputusan tidak melibatkan masyarakat terdampak maupun masyarakat berpotensi terdampak, maka dari itu masyarakat menggugat IPLC tersebut.

5. Asas tata kelola pemerintahan yang baik, yaitu bahwa perlindungan dan pengelolaan lingkungan hidup dijiwai oleh prinsip partisipasi, transparansi, akuntabilitas, efisiensi, dan keadilan;

Dalam hal ini, kebijakan tidak boleh meniadakan aspek kehidupan sosial, ekonomi masyarakat dan lingkungan. Kebijakan harus lahir dari sebuah usulan dan kepentingan sosial ekonomi dan lingkungan. Bupati Sumedang tidak memperhatikan asas ini dalam mengeluarkan IPLC, hal ini terlihat dari cacatnya IPLC karena tidak disertai salah satu kajian dalam syarat teknis.

Kasus gugatan tata usaha negara ini memberikan gambaran bahwa pengembangan ekonomi (investasi) tidak sejalan dengan perlindungan 
lingkungan. Ketiga perusahaan memberikan sumbangan yang signifikan terhadap pertumbuhan ekonomi di kawasan tersebut. Sehingga pengawasan terhadap ketiga perusahaan tersebut cenderung longgar. Kontribusi ekonomi yang besar dari kehadiran ketiga perusahaan tersebut juga menyebabkan ketiga perusahaan mendapatkan prioritas dan kemudahan dalam mengurus perizinan. Akibatnya dampak negatif terhadap lingkungan cenderung terabaikan.

Pemerintah memiliki tanggung jawab mengelola lingkungan dan mencegah pencemaran terhadap lingkungan. Tindakan Pemerintah Kabupaten Sumedang memberikan izin pembuangan limbah cair ke dalam sungai yang telah tercemar, menunjukkan Pemerintah Kabupaten Sumedang tidak memegang fungsi izin sebagai pengendalian pencemaran, sebaliknya hanya melihat fungsi budgeter dari izin tersebut. Dalam memberikan izin, Pemerintah Kabupaten Sumedang hanya memperhatikan syarat-syaratadmnistrasidaripengajuanizin tanpa memperhatikan syarat teknis dari izin tersebut. ${ }^{44}$ Sehingga fungsi izin sebagai pengendalian tidak dijalankan oleh Pemerintah Kabupaten Sumedang. Lebih lanjut, pemberian izin ini menunjukkan Pemerintah Kabupaten Sumedang melupakan tanggung jawabnya terhadap perlindungan lingkungan, dengan membiarkan pencemaran lingkungan terus-menerus dilakukan. Artinya Pemerintah Kabupaten Sumedang telah lalai dalam menjalankan tanggung jawabnya mengelola lingkungan dan menyediakan lingkungan yang sehat bagi masyarakat.

Dalam putusan kasus, Majelis Hakim PTUN Bandung bukan hanya memutus pokok perkara membatalkan sekaligus memerintahkan Bupati Sumedang untuk mencabut Surat Keputusan Bupati Sumedang Nomor 660.31/Kep.509-IPLC/2014 tentang Izin Pembuangan Limbah Cair Ke Sungai Cikijing di Desa Sempur Kecamatan Jatinangor Kabupaten Sumedang Kepada PT. Kahatex tertanggal 7 Juli 2014, Surat Keputusan Bupati Sumedang Nomor 660.31/Kep.784-IPLC/2014 tentang Izin tentang Izin Pembuangan Limbah Cair Ke Sungai Cikijing di Desa Cintamulya Kecamatan Jatinangor Kabupaten Sumedang Kepada PT. Five Star Texile Indonesia tertanggal 30 Januari 2014, Surat Keputusan Bupati Sumedang

44 Hal ini diperkuat oleh pertimbangan hakim dalam Putusan Berkas Perkara Nomor 178/G/2015/PTUN Bandung yang menyatakan bahwa IPLC tidak memenuhi syarat penerbitan karena tidak disertainya salah satu kajian dalam syarat teknis, serta Bupati Sumedang tidak memperhatikan Asas Kehati-Hatian karena telah memberikan IPLC yang limbahnya dibuang ke sungai yang bukan hanya akan tercemar akan tetapi sudah tercemar. 
Nomor 660.31/Kep.198-IPLC/2013 tentang Izin tentang Izin Pembuangan Limbah Cair Ke Sungai Cikijing di Desa Cintamulya Kecamatan Jatinangor Kabupaten Sumedang Kepada PT. Insan Sandang Internusa. Lebih dari itu Pengadilan Tata Usaha Negara Bandung melalui Penetapan Majelis Hakim Nomor 178/G/2015/ PTUN-BDG tanggal 24 Mei 2016 meyatakan penundaan pelaksaan Keputusan Bupati Sumedang terkait Izin Pembuangan Limbah Cair PT Kahatex, PT Five Star Texile dan PT Insan Sandang Internusa. ${ }^{45}$ Salah satu pertimbangan Majelis Hakim menganggap bahwa SK yang dikeluarkan oleh Bupati Sumedang tentang IPLC menyalahi aturan hukum dan tidak memperhatikan aspek kehati-hatian sebagai pejabat publik. Walaupun izin yang dikeluarkan oleh Bupati Sumedang disertai dengan dokumen lingkungan hidup, tetapi dalam dokumen lingkungan hidup tersebut tidak disertai dengan kajian tersendiri tentang dampak pembuangan limbah cair terhadap ikan, hewan, tanah dan kesehatan masyarakat. ${ }^{46}$ Oleh karena tidak ada kajian seperti disebutkan di atas, maka tidak dapat dievaluasi beban pembuangan air limbah ke Sungai Cikijing. Hakim memeriksa ex-tum fakta-fakta yang terungkap di persidangan termasuk bukti tertulis, dan juga melakukan pemeriksaan setempat di Sungai Cikijing diperoleh fakta bahwa kandungan bahan pencemar Sungai Cikijing telah melampaui baku mutu pencemaran air.

\section{Simpulan dan Rekomendasi}

Kasus ini menunjukkan bahwa fungsi izin sebagai pengendali kegiatan di Indonesia pada kenyataannya masih jauh dari yang diharapkan. Langkah besar yang harus ditempuh oleh Pemerintah Indonesia dalam mewujudkannya adalah membangun kesadaran dari seluruh aparat pengambil keputusan untuk menyadari akibat jangka panjang dari pemberian izin terhadap lingkungan, dalam kasus ini Sungai Cikijing yang telah tercemar menjadi korban dari pemberian Izin Pembuangan Limbah Cair oleh Bupati Sumedang terhadap PT. Kahatex, PT.Five Star Textil dan PT. Insan Sandang Internusa. Tidak hanya itu, Pemerintah juga harus melakukan pengawasan kepada perusahaan-perusahaan yang telah diberikan

45 Muhnur Satyahaprabu, Press ReleasePTUN Bandung Cabut 3 Izin Pembuangan Limbah Cair, Bandung 24 Mei 2016.

46 Lihat Syarat Teknis Izin dalam Pasal 23 ayat (2) Peraturan Menteri Lingkungan Hidup Nomor 1 Tahun 2010 tentang Tata Laksana Pengendalian Pencemaran Air 
izinnya, karena itu merupakan kewajiban pemerintah dalam rangka melindungi dan mengelola lingkungan hidup.

Dalam setiap pengambilan keputusan atau kebijakan, pemerintah harus mengedepankan asas kehati-hatian untuk menghindari ancaman terhadap pencemaran dan/atau kerusakan lingkungan hidup. Pada kasus ini, Bupati Sumedang sebelum mengeluarkan IPLC seharusnya menerapkan asas kehatihatian. Selain itu, perlu dilakukan pengawasan ketat atas terbitnya izin pembuangan limbah cair, apalagi limbah cair yang berasal dari wilayah-wilayah hulu suatu kawasan. Pengawasan yang lemah mengakibatkan pencemaran lingkungan sehingga instrumen izin tidak berfungsi sebagai pengendali kegiatan yang berpotensi mencemari lingkungan. Tulisan ini diharapkan menjadi masukan bagi pengambil kebijakan khususnya pemberi izin dalam menilai permohonan izin yang diajukan, sehingga fungsi izin sebagai pengendali pencemaran lingkungan dapat diterapkan secara optimal. 


\section{DAFTAR PUSTAKA}

Adikancana, Santi H D. Tinjauan Yuridis Kewenangan Pemerintah dalam Hal Penegakan Hukum Lingkungan dan Penerapan Sanksi Administratif, dalam Prosiding Perkembangan Hukum Lingkungan Kini dan Masa Depan, LoGoz Publishing: Bandung 2013.

Astriani, Nadia. Instrumen Ekonomi dalam Perspektif Penaatan Hukum Lingkungan, dalam Prosiding Perkembangan Hukum Lingkungan Kini dan Masa Depan, LoGoz Publishing: Bandung 2013

BPLHD Jabar, Pengantar Diskusi (FGD) Bedah Kasus Pencemaran dan/atau Kerusakan Lingkungan di Kecamatan Rancaekek, Kabupaten Bandung: "Meretas Jalan Panjang Menggapai Kebenaran dan Keadilan", http://www.bplhdjabar.go.id/index. php/layanan/k2-categories-2/item/41-pengantar-diskusi-fgd-bedah-kasuspencemaran-dan-atau-kerusakan-lingkungan, diakses pada tanggal 28 Maret 2016.

Danusaputro, Munadjat. 1980. “Hukum Lingkungan, Buku 1 : Umum”. Bandung: Binacipta.

Hardjasoemantri, Koesnadi. 1998. "Hukum Tata Lingkungan". Edisi kedelapan Cetakan kesembilan belas. Yogyakarta: Gadjah Mada University Press.

Helmi, 2012, “Hukum Perizinan Lingkungan Hidup”, Jakarta: Sinar Grafika.

Indonesia. Keputusan Bupati Sumedang No 26 tahun 2013 tentang Izin Pembuangan Limbah Cair.

Indonesia. Peraturan Daerah Kabupaten Bandung No 3 Tahun 2008 tentang RTRW Kabupaten Bandung 2007 - 2027

Indonesia. Peraturan Menteri Lingkungan Hidup Nomor 1 Tahun 2010 tentang Tata Laksana Pengendalian Pencemaran Air

Indonesia. Peraturan Pemerintah Nomor 82 Tahun 2001 tentang Pengelolaan Kualitas Air dan Pengendalian Pencemaran Air. 
Indonesia. Putusan Hakim dalam Berkas Perkara 178/G/2015/PTUN Bandung

Indonesia. Undang-Undang Nomor 32 Tahun 2009 tentang Perlindungan dan Pengelolaan Lingkungan Hidup.

Indonesia. Undang-Undang Nomor 5 Tahun 1986 tentang Peradilan Tata Usaha Negara.

M. Hadjon, Philipus. 1993. "Pengantar Hukum Perizinan”. Surabaya: Yuridika

Pudyatmoko, Y. Sri. 2009. “Perizinan Problem dan Upaya Pembenahan'. Jakarta: Grasindo.

Rangkuti, Siti Sundari. 1996. "Hukum Lingkungan dan Kebijakan Lingkungan Nasional". Surabaya: Airlangga University Press.

Satyahaprabu, Muhnur. Press Release PTUN Bandung Cabut 3 Izin Pembuangan Limbah Cair. Bandung 24 Mei 2016.

Silalahi, M Daud. 2001. “Hukum Lingkungan dalam Sistem Penegakan Hukum Lingkungan Indonesia. Bandung: Alumni. 
